\title{
目前园林绿化的养护管理状况及现存问题
}

胡匡明

内蒙古兴安盟乌兰浩特市园林管理所

DOI:10.32629/btr.v2i11.2597

[摘 要] 随着现代社会的不断发展以及人民群众物质生活水平的不断提高, 也对城市园林绿化工作提出更高要求, 这一工作通常都是在绿化工 程完工后开始, 主要目的是为了最大限度发挥出园林绿化价值, 促进城市发展和建设, 并为人们提供一个健康、舒适的生存空间。本文主要对园 林绿化养护管理状况和现存问题进行了研究。

[关键词] 园林绿化; 养护管理; 现存问题

现代社会发展中, 人们的环保观念越来越强, 因此, 对于城市环境以及 生活质量等都提出更高要求, 在城市发展和建设过程中, 园林绿化工程是 至关重要的内容, 与城市的健康稳定发展息息相关。但就目前实际发展现 状来看, 在我国的园林绿化养护管理工作中, 还存在很多问题, 阻碍了园林 绿化价值的充分发挥。鉴于上述情况, 在今后发展过程中, 我国相关管理部 门必须要提升对上述问题的重视程度, 强化园林绿化养护管理, 并将其作 为城建管理中的重要内容。

\section{1 园林绿化养护管理状况分析}

首先, 随着我国城市化进程的日益加快, 城市环境恶化问题也日趋严重, 究其根本, 主要是因为人们过度追求经济效益, 忽视了对城市生态环境的保 护。众所周知, 以牺牲环境为代价的经济发展并不长久, 由于这种矛盾的存 在, 也对我国城市发展造成了直接影响。与此同时, 由于各地政府部门对于 园林绿化养护管理工作的重视程度比较低, 因此并不能制定出完善可行的 工作方案, 甚至没有明确的工作流程, 这些都对园林民绿化养护管理工作质 量造成了直接影响 ${ }^{[1]}$ 。其次, 在当前的园林绿化养护管理工作中, 由于资金比 较缺乏, 因此也对这一工作的顺利开展造成了直接影响, 同时也大幅度降低 了园林绿化养护管理工作质量和效率。在我国一些经济比较发达的区域, 人 们已经提升了对园林绿化养护工作的重视程度, 并加大了资金投入力度, 但 鉴于落实度较低, 因此并不能取得理想效果。而在我国很多经济欠发达的区 域, 园林绿化养护管理工作的开展, 基本上都是为了应付上级检查, 敷衍了 事, 加之地方经济紧张, 因此并没有过多的资金投入到这项工作当中, 从而 也阻碍了园林养护管理工作的顺利开展, 最后, 在我国当前的园林绿化养护 管理工作中, 由于专业养护管理人员比较缺乏, 因此也会对工作质量造成直 接影响。一方面, 由于资金缺乏, 因此并不能对专业、优秀的养护管理人员 形成巨大吸引力; 另一方面, 由于园林养护工作环境比较恶劣和艰苦, 因此 人员流动问题十分常见。目前的养护管理人员基本以外来务工人员为主, 这 些人员大多缺乏园林养护管理常识, 专业技术水平较低, 且在操作方面缺乏 针对性和技术性, 在此情况下, 直接降低了绿化养护管理质量, 且植物成活 率也大打折扣, 这些都对园林绿化预期效果产生直接影响 ${ }^{[2]}$ 。

\section{2 做好城市园林绿化养护管理工作的有效建议}

2. 1 提高对园林绿化养护管理工作的重视程度

要想确保城市园林绿化养护管理工作的顺利开展, 首先就是要提高对这 项工作的重视程度, 实践过程中, 在园林绿化工程施工、设计等环节中, 都要充 分考虑养护管理内容, 并结合实际情况进行改进和完善。另外, 各地的园林部 门以及政府部门, 还要结合实际情况对完善可行的园林绿化养护管理方案进 行制定, 强化监督, 做好宣传工作, 使公众都能够认识到这项工作开展的重要 性, 并能够自觉主动地爱惜园林, 保护生态环境。另外, 对于园林绿化养护工作, 还要制定出完善的技术规范, 结合技术要求、管理需求, 提升养护管理效果 ${ }^{[3]}$ 。

\section{2 不断提高园林绿化养护管理人员的综合素养}

园林绿化养护管理人员的综合素养与养护管理工作质量信息相关, 只 有不断提高养护管理人员的综合素养, 才能够为园林绿化工程的长足发展 奠定基础。首先, 园林管理部门需要加大对专业技术养护管理人才的引进 力度, 并在其正式上岗之前进行教育培训, 定期开展交流讲座活动, 同时还 要对国内外先进的工作经验进行借鉴, 取其精华去其糟粕, 不断提升养护 管理人员的综合能力和素养, 培养出一支工作能力高、专业性强的管理团 队。与此同时, 还要强化对养护管理人员的道德教育, 增强其使命感和责任 感, 为养护管理工作质量提供保障。为了实现上述目标, 还需要对现有的考 核、培训机制进行健全, 以此为人员培训效果提供保障, 对于培训过程中表 现优异的人员进行表扬和奖励, 以提高其参与热情, 凸显培训实效性。

2. 3强化资金支持和技术引进

要想做好城市园林绿化养护管理工作, 还要强化资金支持和技术引进, 城市园林绿化养护管理工作具有工作内容繁琐、周期性长等特征, 随着现代 科技的不断发展, 各种各样的先进设备和技术都被广泛的应用到养护管理 工作中, 从而也需要更多的资金做保障和支持。因此, 养护管理部门必须要 强化与其他部门的沟通与协调, 结合养护项目和施工季节的不同, 做好资金 的预算和规划, 使各个环节工作的开展都能够有足够资金。与此同时, 还要 不断提升养护工作的技术水平和机械化程度, 对各种现代化先进的机械设 备进行引进, 具体如除草机、修剪机、自动喷灌机等等, 在技术方面, 可根据 园林绿化特点, 对植物成活率、病虫害防护、排水设施、设备维护等问题进 行全面考虑, 对国外先进技术进行引进, 从而大幅度提升园林绿化管理工作 质量和效果, 节约成本, 使养护管理工作能够在规定时间内保质保量完成 ${ }^{[4]}$ 。

\section{3 结语}

综上所述, 园林绿化养护管理在城市化发展过程中占据着十分重要的 地位, 因此必须要引起我国相关部门的高度重视。实践过程中, 需结合实际 情况采取相应的发展措施, 积极引进各种现代化先进技术和设备, 提高园 林养护管理工作质量, 并充分发挥出其实际作用和价值, 最终达到改善和 美化城市环境、提高市民生活质量的目的。

[参考文献]

[1]赵淑琴.兰州市园林绿化养护管理市场化运作存在的问题与对策 [J].河南农业,2018,463(11):53-54.

[2]刘志为,李雪松.城市园林绿化养护管理现存的问题及解决对策[J]. 农村实用科技信息,2016,45(6):24。

[3]汤茜.浅谈城市园林绿化养护管理中存在的问题及对策 [J].建筑工 程技术与设计,2016,(35):258.

[4]李正.浅谈城市园林绿化养护管理及存在问题与对策[J]. 中小企业 管理与科技(下旬刊),2016,(7):116-117. 